\title{
THE MODALITIES AND ROLES OF LOCAL GOVERNMENTS TO FACE TERRORISM ISSUES IN INDONESIA: THE CASE STUDY OF MALANG RAYA REGION
}

\author{
Gonda Yumitro, Dyah Estu Kurniawati, Saiman, Dion Maulana Prasetya, \\ Shannaz Mutiara Deniar ${ }^{1}$ \\ Universitas Muhammadiyah, Malang
}

\begin{abstract}
:
This article examines the role of local governments in facing the threat of terrorism in Indonesia, selecting as a case study the Malang Raya region, which consists of Malang City, Malang Regency, and Batu City. The selection of these three regional governments is interesting because some of the suspected terrorists were arrested and arranged their actions to some other places in Indonesia from this region. By using the concept of securitization, this research finds that the securitization done by the local governments is influenced by internal and external modalities they have for facing terrorism. Therefore, the mapping of the modalities in this research contributes to the local governments gaining more legitimacy in constructing threats and make speech acts work well. It is also the modalities which determine whether the process will be successful or failed. However, there were some obstacles found which encouraged the government to collaborate with other stakeholders, such as civil societies from Pesantren, to face the issues of terrorism in the region.
\end{abstract}

Keywords: Government, Malang, Modalities, Terrorism, Roles

Título en Castellano: Las Modalidades y los Roles de los Gobiernos Locales frente a las Cuestiones de Terrorismo en Indonesia: el Estudio de Caso de la Región de Malang Raya

\section{Resumen:}

Esta investigación estudia el papel de los gobiernos locales en contrarrestar la amenaza del terrorismo en Indonesia, centránndose en el estudio de caso de la región de Malang Raya, que incluye Malang City, Malang Regency y Batu City. Estos tres gobiernos regionales han sido elegidos porque algunos presuntos terroristas han sido detenidos y organizaron sus operaciones en otros lugares de Indonesia desde esa zona. Basándose en el concepto de securitización, el estudio demuestra que la securitización liderada por los gobiernos locales está influenciada por sus modalidades internas y externas a la hora de afrontar el terrorismo. En consecuencia, el estudio de estas modalidades intenta conseguir que los gobiernos locales logren dar una mayor legitimidad a su discurso sobre lo que construyen como amenazas. También son estas modalidades las que determinan el éxito o el fracaso del proceso. Sin embargo, existen obstáculos a los que se han enfrentado los gobiernos que les han inducido a colaborar con otros actores de la sociedad civil como los Pesantren para encarar al terrorismo en la región.

Palabras Clave: Gobierno, Malang, Modalidades, Terrorismo, Roles

Copyright $\odot$ UNISCI, 2019.

Las opiniones expresadas en estos artículos son propias de sus autores, y no reflejan necesariamente la opinión de UNISCI. The views expressed in these articles are those of the authors, and do not necessarily reflect the views of UNISCI

${ }^{1}$ Gonda Yumitro is Associate Professor at the Department of International Relations, Universitas Muhammadiyah Malang, E-mail: gonda@umm.ac.id. Dyah Estu Kurniawati is Assistant Professor at the Department of International Relations, Universitas of Muhammadiyah Malang, E-mail: dyahestu@gmail.com. Saiman is Associated Professor at the Department of Governmental Science, Universitas Muhammadiyah Malang, E-mail: saimanmhdris@gmail.com. Dion Maulana Prasety is Assistant Professor at the Department of International Relations, Universitas Muhammadiyah Malang, E-mail: dionprasetya@umm.ac.id. Shannaz Mutiara Deniar, is Lecturer at the Department of International Relations, Universitas Muhammadiyah Malang, E-mail: shannazdeniar@umm.ac.id.

DOI: http://dx.doi.org/10.31439/UNISCI-80 


\section{Introduction ${ }^{2}$}

Terrorism has become a global phenomenon since the 9/11 attacks in 2001 to Pentagon and WTC building. ${ }^{3}$ After that, the war against terrorism has become a global phenomenon, including in Indonesia, a country that became one of the targets of large-scale acts of terror. This article examines the roles of local governments - including Malang City, Malang Regency, and Batu City - to face the threat of global terrorism. The region of Malang Raya historically had very close relations with the issues of terrorism. Dr. Raid Azhari, the main suspected actor of the Bali bombings I and II, was captured in Batu City in 2005. It became the first alarm that the Malang area was not safe from the threat of terrorism. ${ }^{4}$ Dr. Azhari was part of a global terrorist network, Jemaah Islamiyah (JI), an organization that has a direct relationship with Al Qaeda. ${ }^{5}$

In addition to the JI network, the region of Malang had also been related to the Islamic States of Iraq and Syria (ISIS). In August 2014, the ISIS commander who came from Malang, named Salim Mubarak Attammimi, stated his threat to fight against the Indonesian military. ${ }^{6}$ In the video which he published through youtube, he stated his threat to TNI (National Military of Indonesia), Police, and Banser commander. Furthermore, Salim had some followers living in Malang. It was proven by the arresting of three suspected terrorists as well as his cadres in 2015. ${ }^{7}$ Two of them, namely Abdul Hakim Munabari and Junaedi, were reported to have traveled to Syria to join ISIS, before finally returning to Malang. ${ }^{8}$

The following year, 2016, four suspected terrorists were arrested in Karangploso, Malang Regency. The four terrorists captured were linked to the terror that occurred a month earlier on Tamrin street, Jakarta. In the absorption conducted by Detachment 88, they found some evidence such as Molotov bombs, jihadist books, face covers, and others. ${ }^{9}$ Two years before, in 2014, in the same area, there was an explosion at the Mandiri ATM, which was allegedly an act of terrorism. Finally, in 2017, a suspected terrorist who was connected to Salim Mubarak Attammimi, Kiki Rizky, was arrested at Kasin, Malang City. ${ }^{10}$

The sequence of events indicated two crucial things: first, Malang Raya region has become a terrorist hideout since the location is strategic for the newcomers; second, the threat of global terrorism imposed a direct impact on the daily lives of people in Malang, especially in this globalization era where people or circumstances happen in one place affect those happen in other areas. Therefore, as the institution in charge of helping the people facing and solving their problems, governments bear the duties to issue some policies in the manifestation of their

\footnotetext{
${ }^{2}$ The research for this article is funded by the Indonesia Ministry of Higher Education, Research and Technology, under the Grant of Penelitian Dasar Unggulan Perguruan Tinggi (PDUPT) and is supported by Universitas Muhammadiyah Malang

${ }^{3}$ Comfort, Louise K. and Kapucu Naim: "Inter-Organizational Coordination in Extreme Events: The World Trade Center Attacks, September 11, 2001", Natural Hazards, Vol.39, nº 2 (2006), pp. 309-327.

${ }^{4}$ Muradi: "The 88th Densus AT: The Role and the Problem of Coordination on Counter-Terrorism in Indonesia", J. Pol. \& L. Vol. 2, no 3 (2009), pp. 85.

${ }^{5}$ Mubah, A.S. (2012): “Teroris versus Globalisasi”, Surabya, PT Revka Petra Media, pp. 67.

6 Jerard, Jolene: "Rise of Islamic State Networks in Indonesia", RSIS Commentaries, 20 January 2016, at https://www.rsis.edu.sg/wp-content/uploads/2016/01/CO16011.pdf

${ }^{7}$ Nuraniyah, Navhat: "Returning Indonesian Fighters from Syria and Iraq: Learning from the Past", RSIS Commentaries, 17 February 2015. at https://www.rsis.edu.sg/wp-content/uploads/2015/02/CO15035.pdf

${ }^{8}$ Tetuko, Bayu and S. Muryantini: "Upaya Pemerintah Indonesia Dalam Menghadapi Penyebaran ISIS," Jurnal Studi Diplomasi Dan Keamanan, Vol. 8, nº 2 (2016), pp. 12.

${ }^{9}$ Sahrasad, Herdi and Al Chaidar: "Indonesian Terrorist, ISIS, And Globalization Of Terror: A Perspective," Ahkam: Jurnal Ilmu Syariah, Vol.18, n. 1 (2018), pp. 1-22.

${ }^{10}$ Yumitro, Gonda, D.E. Kurniawati, and Saiman, "Terrorism Issues and the Development of Transnational Islamic Movements in The Region of Malang”, International Conference on Islam and Muslim Societies (ICONIS) (2018), pp. 22. at https://www.academia.edu/37847096/Proceedings_ICONIS_International_Conference_on_Islam_and_Muslim_ Societies_-Part_One
} 
roles.

While terrorist acts have appeared in the area outside the capital, the roles of local government have been very limitedly discussed, both within political as well as academic circles. Anthony Bergin explained that local government is the 'forgotten actor' in countering terrorism, especially when it comes to consequence management and resilience lives locally. He added that the primary responsibility of protecting people's security is within the domain of the central government; however, the terrorist attacks will occur within local government areas. ${ }^{11}$ In line with Bergin, Anindya taking a lesson from the case of Purwakarta Regency concluded that the roles of local government consist of providing suitable programs for former terrorists to reintegrate into local society as well as providing financial assistance. It shows that the roles of local government are not negligible in facing any threat of terrorism. ${ }^{12}$

This article, therefore, will try to explore the efforts of local government in the region of Malang Raya dealing with terrorist threats by analyzing how it perceives and acts through securitization theory. It is essential to do for two reasons: first, there are limited studies about terrorism in Indonesia done from the local government point of view. If any, it does not try to unpack the process of securitization done by the government; second, there is no singleconsensus meaning on the terrorist threat, especially between the government and the people what the government sees as a threat is often perceived differently by the people who rather consider the act as a religious movement instead of a threat. That circumstance often ended in the passive participation of the people in countering terrorism. This study, therefore, tries to fill the gap by unpacking the perception about the threat of the government and will try to answer the questions of how the local government in the Malang Raya region plays roles in facing the issue of terrorism. However, before explaining the roles, writers firstly explain the concept of securitization, the perspectives of government toward the terrorist threat, and the modalities owned by the government to face the issues

\section{Securitization and Local governments}

Security studies in international relations were focused traditionally on the survival of a nationstate, not on local governments and their possible security roles. There are three main approaches adopted in security studies: realism, liberalism, and constructivism. ${ }^{13}$

This study uses constructivist thinking frameworks - more specifically, the concept of securitization from the Copenhagen School. ${ }^{14}$

This approach aims to achieve a better understanding of six ' $w$ ' questions: who securitizes the issues?; on what matters?; for whom?; why?; with what results?; and under what conditions? ${ }^{15}$ Moreover, Catherine Charrett made more specific operational questions on how to understand securitization by asking whether the securitizing actor has managed to mobilize support? Who is the audience, and what are the facilitating conditions? Have any extraordinary actions been taken? Moreover, what might be the impact of such securitizing acts on other

\footnotetext{
${ }^{11}$ Bergin, Anthony: "Local Government and Australian Counter-Terrorism Strategy", Journal of Policing, Intelligence and Counter Terrorism, Vol.12, $\mathrm{n}^{\circ} 1$ (2017), pp. 74-77.

12 Anindya, Chaula R.: "Reintegrating Former Terrorist Inmates: Role of Local Government", RSIS Commentaries, 29 November 2018, at

https://dr.ntu.edu.sg/bitstream/handle/10220/46754/CO18201.pdf?sequence=1

${ }^{13}$ Peou, Sorpong: "Realism and Constructivism in Southeast Asian Security Studies Today: A Review Essay," The Pacific Review, Vol. 15, n ${ }^{\circ}$ 1, (2002), pp. 119-138.

${ }^{14}$ Buzan, Barry, et al (1998): Security: A New Framework for Analysis, Colorado, Lynne Rienner Publishers, pp. 33.

15 op. cit., pp. 32
} 
units?. ${ }^{16}$ Thus, it is the actor who decides what issues to be perceived as a threat, or in other words, the securitizing actor is the one who puts forward a claim to securitize an issue.

The actor whose perception will be examined here is the local governments of Malang Raya, consist of Malang city, Batu city, and Malang regency. We have conducted several interviews with local government representatives as well as the police and the army to find a broader understanding of how such actors securitize a particular issue. The referent object is the people of the Malang Raya region. The issue to be securitized here is terrorism, or even more comprehensive - radicalism, in Malang Raya. Hence, it will be discussed further about the conditions causing the securitization and what outcomes are.

This research finds that the securitization done by the local governments is influenced by some modalities they have. The modalities help the local governments to gain more legitimacy in constructing threats and make speech acts work well. It is also the modalities which determine whether the process will be successful or failed. This form is what Copenhagen Scholars mean that securitization is an intersubjective process. As Balzacq argues, the role of the audience is central in securitization. He insists that the empowering audience must agree with the claims made by the securitizing actor. In other words, securitization is satisfied by the acceptance of the empowering audience of a securitizing move. ${ }^{17}$ In this case, the acceptance of the audience is also influenced by the modalities of the local governments. The kind of modalities that the governments have will be described more detailed in the next part.

It cannot be neglected that national events can no longer be separated from global factors, both as direct and indirect causes. Therefore, the shift of the security concept in the context of international relations also automatically influences the definition of internal security. Shifting the definition and meaning of internal security can be seen from the 2015 Indonesian Defense White Paper issued by the Ministry of Defense. ${ }^{18}$ The book explains that changes in the global strategic environment have a significant impact on national security. The form of the threat becomes increasingly complex and multidimensional, both in the way of military and non-military threats, or a combination of both (hybrid). ${ }^{19}$

Although it has been included in the white paper, Indonesian local governments are generally still not aware of the threat of terrorism. Edward Newman argued that such condition happened because of the weakness of Indonesia as a state, and the limited control over the vast territory of this country. ${ }^{20}$ In East Java, a Governor Regulation was issued to prohibit the activities of global terrorist organizations. However, the 2014 Governor Regulation concerning the Prohibition of the existence of the Islamic State of Iraq and Syria (ISIS) movement, is too narrow, because the threat of global terrorism is not only limited to threats from ISIS but also consists of various kinds of organizations with affiliates that are also diverse. ${ }^{21}$ In the region of Malang Raya, as mentioned above, there are at least two terrorist groups affiliated with ISIS

\footnotetext{
${ }^{16}$ Charrett, Catherine: "A Critical Application of Securitization Theory: Overcoming the Normative Dilemma of Writing Security”, International Catalan Institute for Peace, Working Paper no. 2009/7 (December 2009), pp. 148 at SSRN: https://ssrn.com/abstract=1884149

${ }^{17}$ Balzacq, Thierry (2011): Understanding Securitisation Theory: How Security Problems Emerge and Dissolve, New York, Routledge.

${ }^{18}$ Ministry of Defence Republic of Indonesia (2015): "Buku Putih Pertahanan Indonesia", Ministry of Defence, at https://www.kemhan.go.id/wp-content/uploads/2016/04/BPPI-INDO-2015.pdf.

${ }^{19}$ Brown, Leslie F: "Twenty-First Century Warfare Will Be Hybrid", Thesis,.......... U.S. Army War College, (March 2011), at http://indianstrategicknowledgeonline.com/web/21\%20cen\%20hybrid.pdf.

${ }^{20}$ Newman, Edward: "Weak States, State Failure, and Terrorism," Terrorism and Political Violence, Vol. 19, No. 4 (2007), pp. 463-488.

${ }^{21}$ Sayyidati, Adibah: "Potret Jawa Pos Tentang Islamic State of Iraq and Syria (ISIS) Di Jawa Timur Dalam Perspektif Jurnalisme Perdamaian,” Jurnal Pekommas, Vol. 3, nº 1 (April 2018), pp. 93-102.
} 
and Al Qaeda. Thus, the narrowing of the meaning of terrorism, which only refers to one particular organization, becomes an urgent problem.

\section{Government Modalities in Facing Terrorism Issues}

The government is one of the main actors to solve the issues of terrorism by its political power. By producing some strategic policies, the government is expected to optimize the use of its modalities. As a legitimate institution, the government has power, which is different from the power of other stakeholders. Therefore, the understanding of the modalities of the government to face the issues of terrorism is very crucial.

Since constructivism is used as the tool to analyze this topic, the perspective of government toward the issue is critical to understand its modalities and the expected solutions to the problems. Therefore, the government needs to understand the roots of terrorism in the regions and the level of its impacts on the social, economic, and security of the people. Generally speaking, the scholars said that the threat of terrorism is dangerous and will suffer the social, economic, and security feeling within society. ${ }^{22}$

Based on the results of in-depth interviews and Focus Group Discussion (FGD), the government modalities to face the issues of terrorism can be divided into two: internal and external.

\subsection{Internal Modalities}

The internal modalities in this context mean the resources owned by the government within its institutions (internal) without any influencing factors from other institutions to face the issues of terrorism. These internal modalities consist of:

First, intelligence capabilities and collaboration with society. As the state institution needs to give the best services to the society, the government have specialized abilities to run its function, such as intelligence and collaboration capabilities. Somehow, a particular agent of the government has more concern about these capabilities compared to others. For instance, the writers found the evidence that the police have excellent intelligence capabilities in identifying any potential terror in Malang. The police of Malang city said that they have an excellent skill to define the threats by monitoring the suspected movements of terrorists in Malang City. The intelligence unit does the monitoring process after getting some information from higher units, either provincial or central, with the help of pesantren leaders. ${ }^{23}$

Moreover, the Batu City Police appealed to the public to be aware of the presence of new residents in Batu City. The way to increase people's vigilance is by making the rule requiring the guests to make a report when staying in one house for more than 24 hours. This policy is essential because the existence of this city as a tourism area makes more people from various places come and leave this city. Without collaborative control conducted by the government and society, the effort to protect the city from the threat of terrorism is quite severe, based on its historical background. Furthermore, this policy also becomes the way of the government to involve the citizens with the issues of terrorism in Batu City. ${ }^{24}$

Second, the accuracy of terrorist movements mapping in the region of Malang Raya. The capability to create a mapping of the issues is vital to find a solution to the problems. In the case of terrorism, the understanding of the roots of terrorism, as well as the networks,

\footnotetext{
${ }^{22}$ Sönmez, S., Apostolopoulos, Y., and P. Tarlow: "Tourism in Crisis: Managing the Effects of Terrorism", Journal of Travel Research, Vol. 38, nº 1 (1999), pp. 13-18.

${ }^{23}$ Interview with Malang City Police Resort intelligence member.

${ }^{24}$ Interview with Batu City Police Resort intelligence member.
} 
financial support, the activities, and the innovation of the groups should be valid. ${ }^{25}$ Moreover, those data also need to be analyzed to picture the real issues as the consideration for finding the best solution.

In Malang, the government has the accuracy in mapping terrorist movements as the modality to face these issues. The government believes that since terrorism issues are susceptible, they cannot be rushed to take action against individuals or groups that are allegedly exposed to radicalism. The misconduct in taking action to fight terrorism can cause new problems, for example, the complaints from society. Therefore, after finding some essential data, they would invite the scholars as well as Islamic clerics to validate the information.

This validation should be done since the government cannot state that certain groups are a nest of terrorists without strong evidence. Sometimes, there were individuals with similar characteristics or appearance with a particular radical group, but they have different characteristics and point of views regarding the issues of terrorism. People often identify the preaching group as a nest of terrorists. However, the police tried not to be haphazard in setting one group as a nest of terrorists because they were aware of the cases in Malang are mostly because of individual factors than groups.

This capability to depict the real picture of terrorism' map is one of the prominent modalities of government in Malang to face the issues of terrorism. The mistake in taking the conclusion will raise massive complaints from the Islamic groups.

Third, humanist and family relational approaches to pesantren, Islamic groups, and the public to socialize the threat and solution in facing the issues of terrorism. The humanist and family relations here mean that governments can communicate and interact with society by understanding the human and social behavior to build a strong feeling of convenience among them. ${ }^{26}$ By these approaches, the government can easily communicate their policies and plans to the society.

Therefore, building a connection between the government and society is crucial. Since the governments have the power, they need to be actively communicating and interacting with the people. In the case of Malang, the former mayor of Malang city, Abah Anton, often came to the society and had direct interaction with them. In some places, he gave financial aids to build public facilities. While realizing that people feel conveniences with the government, Abah Anton intensively started to socialize his policies, including also the importance of vigilance to counter-terrorism.

Another example was that the police also often visited pesantren and Islamic groups in their area to build synergy between the elements of society and government to fight terrorism. In 2018, the police of Malang city also invited Aa' Gym (one of the famous national preachers) to come and give preaching in Malang with the topics on the message of Islamic peacefulness.

In that preaching, the polices collaborated with all levels of governments and society to come and join the event. As a result, the program became viral, and thousands of people participated in that program.

This collaboration between government and society through humanist and family relational approaches has grown the closer connection between the government and society. Therefore, various programs, including also the efforts of facing the issues of terrorism, can be

\footnotetext{
${ }^{25}$ Ranstorp, Magnus: "Introduction: Mapping Terrorism Research - Challenges and Priorities." In Ranstorp, Magnus (ed.) (2007): Mapping Terrorism Research: State of Art, Gaps and Future Direction, New York, Routledge, pp. 1-28.

${ }^{26}$ Schlesinger, Arthur Jr: "The Humanist Looks at Empirical Social Research," American Sociological Review, Vol. 27, no 6 (December 1962), pp. 768-771.
} 
implemented by this kind of modality.

Fourth, being proactive in responding to terrorist movements. Proactive means are doing current action to anticipate future problems. ${ }^{27}$ In the case of terrorism, it means that governments have modalities to conduct actions after getting information about the movements of terrorist groups.

During both in-depth interviews and FGDs, the writers found data that the Government of Malang city and Forkopimda has made proactive policies on the issues of terrorism. For example, after getting the information, they will confirm the issues to the people living nearby of the location. If needed, the socialization to protect the possible victims because of the terrorist attack will also be arranged by the police.

Although they do not directly play a role in taking action against suspected terrorists, the government of Malang, the police, and the military played significant roles in securing the region and supplying intelligence information through the Regional Intelligence Community (Kominda). Since there is a possibility of the terrorist group to make sudden attacks, this proactive step is an essential modality of the Malang government. ${ }^{28}$

Fifth, the efforts of the government to assist the prisoner inmates in and collaborate with ex-prisoner inmates as parts of deradicalization programs. The existence of the prisoner and exprisoner of terrorist inmates can be a very prominent modality of government to face the issues of terrorism. By its power, the government can use them as part of the deradicalization programs.

In the case of prison inmates, the police have been actively carrying out deradicalization, in the form of spiritual assistance to terrorist prisoners in prisons. They used to invite Islamic clerics to give preaching at the jail as an effort to neutralize the radical understanding of the prisoners.

Slowly, through routine and systematics programs, the government open the mind of the radicals to see the Islamic views and the reality based on the context to bring the spirit of peace in Islam.

This excellent connection with the ex-prisoners of the terrorist inmates also is used by the government as the modality to face the issues of terrorism. For instance, the police still assisted some former terrorist inmates after being released from prison. Through this connection, the police obtain information on the movements of terrorist groups and the region. Moreover, the ex-prisoner of terrorist inmates also can be the person in charge to connect the polices with the active terrorist inmates.

Finally, having members who understand the knowledge of Islam. The final internal modality is related to the expertise of some policies in the field of religion. This condition can be categorized as a modality because it helps the police mapping various religious-based radical movements. Without this expertise, the police were prone to resistance from individuals, preaching groups, and pesantren, which consider the police to go too far to interfere in Muslim worshipping. However, the existence of some police personnel who understand Islam well enables them to stay close with some of these Islamic groups.

\subsection{External Modalities}

The external modalities are related to the capacity of the government to collaborate with other institutions to face the issues of terrorism. These modalities work effectively with the support

\footnotetext{
${ }^{27}$ Giri, Jay: "Proactive Management of the Future Grid", IEEE Power and Energy Technology Systems Journal, Vol. 2, no 2 (June 2015), pp. 43-52.

${ }^{28}$ Interview with Bakesbangpol Malang City
} 
of the internal ones. Some of those external modalities can be explained as follows.

The first external modality has a close relationship with the third internal modalities. It is the humanist and family relational approaches that become an external modality using support from pesantren and preaching groups. Both the police and the military have been actively involved in the preaching programs held by religious leaders in the area of Malang. It is common for the government, police, and military to take part in the preaching attended by national preachers. The closeness to the pesantren and the preaching groups has its advantages for the government to work investigating the networks and finding the solution of terrorist threats in the area.

Moreover, the close relations and excellent communication among the stakeholders minimize the suspicion from each other. Communication also can be used as a means of sharing information among the parties to face the issues of terrorism. For example, one of the pesantren leaders often provides information to the police about individuals who have the seeds of terrorists. On the other hand, while government intelligence found the suspected persons want to influence the notions of the people to support their radical movement, the government can invite pesantren leaders and preaching groups to face such issues.

Second, the government gains support and trust from the pesantren and preaching groups. As a result of excellent communication of government with the other stakeholders, the government has gained supports from pesantren and preaching groups to fight against terrorism in the region. Based on in-depth interviews and FGDs, all pesantren and preaching groups support police efforts in dealing with the issues of terrorism in Malang. This form of support can be seen from their participation against terrorism as well as the efforts to strengthen peaceful religious values within the society.

Sometimes the government consist of the mayor, police, and military come to various mosques in the region together with some of the Islamic clerics from pesantren and preaching groups. Through this information program, they convey the message of Islam to protect the security of the others and against all forms of violence. The people also fell more convenient and closer to their elites through such |informal events.

Finally, the government also gains support from former terrorist inmates. The support of former terrorist prisoners is the most crucial external modality of government to face the issues of terrorism since they know the historical background, histories, development, and the networks of the terrorist group in the region. Based on in-depth interviews with Malang City Resort Police revealed that former prisoner M. Kholili often became a vital informant related to the terrorist movement in Indonesia. Information from Kholili can be developed into an advanced investigation or just mapping the terrorist movement in Malang.

\section{The Roles of the Government in Facing Terrorism Issues}

The government modalities, as explained before, have been used to face the issues of terrorism in the region of Malang. Without the optimization of modalities function, the effort to fight against terrorism cannot work well. Based on the result of the research, the roles of government can be divided into four: preventive, proactive, curative, and rehabilitative, as explained below.

First, preventive roles of government are related to intelligence activities, mapping of radical groups, and socialization of the community. The first preventive role is carried out by conducting intelligence operations continuously. The intelligence function is carried out by three government institutions, namely the regional government, the police, and the Indonesian military. Local government performs the intelligence function using the Kominda (Regional Intelligence Community) framework.

Kominda itself is under the coordination of one of the government organs, namely the 
Bureau of National Unity and Politic (Bakesbangpol). It consists of all corps that have intelligence functions, which are facilitated by the Bakesbangpol regional sector. In carrying out its functions, Kominda communicates with fellow members through the WhatsApp group, which is used as a medium to disseminate information to all members of Kominda, regarding who and where potential places are monitored.

Moreover, the police also have a more sophisticated intelligence function. The police intelligence agency occupies the second structure of the intelligence network at the city/regency level, after Kominda. Based on in-depth interviews with the police, the researchers found that intelligence information was very detailed. For instance, in the case of ISIS, they know the history of ISIS in Indonesia and its development in Malang, their characteristics, the funding actors, the pattern of movements, the relations with the ISIS in Iraq and Syria, and their infiltration in Malang.

The results of intelligence activities above were used as a mapping of any individuals or groups that should be suspected of being exposed to and spreading the radical ideology. For example, the police have information about several vulnerable groups exposed to radicalism. The results of the mapping, as a further step, were used as a reference for the government in the dissemination of the dangers of terrorism and radicalism in vulnerable areas. So that the socialization carried out by the government is segmented and targeted.

Through the intelligence process, the threats of terrorism in the area of Malang have already declined in terms of number of attacks, victims and publication of incidents and threats in the last few years. Before the terrorist groups can implement their plans, the government has already been aware of some preparations thanks to the collaboration with various operatives, including the society in general. Providing an early warning on the possibility of a terrorism attack, the local government can put in practice some anticipation efforts already developed, such as the socialization of the probability and impact of the threat on the community and the means and tools to capture the main actors of terrorist acts.

Moreover, after finding the roots of terrorism, the prevention of terrorist action can be done by working on the causes of terrorism. For instance, the government of Malang has actively increased the economic welfare of the people and has supported the rise of education access within society. These two factors have been realized as the main reason for terrorism issues. Furthermore, the local government also has intensely communicated with the exprisoner inmates to find the best solutions for those with radical approaches regarding Islam.

By these kinds of actions, the local government has obtained more robust supports from the people since they believed that the government is committed to protecting their security. Moreover, the government has also been closely connected and often in communication with some moderate Islamic leaders in order to prevent and protect the population from radical ideologies spread by Islamic movements.

Second, the proactive role relates to the government's response to the terrorist movement. Proactive means that the government actively plays its roles in optimizing all of its modalities to face the issues of terrorism after getting the information on the existence of terrorist movement. Therefore, this proactive is vital in responding to any information or the movements of terrorist groups within the area. The function of these roles is to minimize the effect of terrorist groups on society. At least, there are some methods of showing proactive roles of government to face the issues of terrorism. Some of those roles are strengthening law enforcement, optimizing the resources for counterterrorism programs, designing new types of 
team training, and establishing collaboration with other stakeholders. ${ }^{29}$

In the case of Malang, the government has instructed the head of villages to disseminate ISIS as a prohibited organization as well as to focus on the early detection of terrorism and radicalism in Malang. Whoever joins the organization will get the punishment from the government. This kind of rule does not consider a crime the affiliation of one person to movements or groups that try to defend the equality before the law and to guarantee law enforcement without any spurious intervention.

Despite producing the regulations, the government also invited some prominent Islamic clerics, like Aa' Gym, to perform preaching in Malang. Through these events, the government wants to explain that they are collaborating with Islam and do not assume that Islam is the source of terrorism. This type of resource optimization to face the issues of terrorism has become a new method of collaboration with other stakeholders. In the June 2018 programme, the government invited to participate to all the members of the society.

Through this proactive role of the government, people have a sense of security within the society. In the case they find any suspicious activities conducted by the new or an unknown group around their area, they immediately give a report to the security authorities for further actions. Moreover, they also can collaborate well with the government to fight all forms of violence, especially those accomplished in the name of religion.

Third, at the curative level, the government assists terrorist prisoners in prisons to be deradicalized. This role is a process of healing for the terrorist defendants through prison sentences and some other treatments. During the sentence, the government continuously assisted the terrorist inmates to change their minds and perspective of solving social problems. The trust that the government also has the same mission to bring justice and welfare within the society became part of the programs. The collaboration of government and people, including also the Islamic movement, is one of the prominent issues for the success of the mission.

Therefore, for this curative role, the police invited respected religious leaders in the Malang city to give preaching in Lowokwaru Prison. This program was held to deradicalize the minds of terrorist prisoners as well as to prevent radical ideologies from spreading to other inmates. As a result of these programs, there were some of the terrorist inmates have become part of the deradicalization project. They expect that all people can collaborate with the government to face the issues of terrorism, especially in the region of Malang.

Finally, the rehabilitative role is carried out by cooperating with an ex-terrorist inmate as partners in efforts to de-radicalize terrorist defendants and the general public. This role was carried out after the government succeeded in de-radicalizing former terrorist inmates. Once the ex-prisoners are free from prison sentences, the government took the initiative to collaborate with the individual to carry out socialization or de-radicalization efforts in their area.

Through the sharing of ex-terrorists, society clearly understands the process of the ideology changing of the persons joining the terrorist groups. Besides, they also became aware of some of the groups which recruit and trap people to join radical movements. The information of the ex-terrorists mostly tended to be clear and pictured the real movement and development of the terrorist groups. By this collaboration as rehabilitative roles, the government also runs the preventive as well as the pro-active roles in facing the issues of terrorism.

One of the examples conducted by Malang police to play their rehabilitative roles was the cooperation with Ali Fauzi. Since some years ago, Ali Fauzi founded the Foundation of

\footnotetext{
${ }^{29}$ Rehm, M. K., and Rehm, W. R: “Terrorism Preparedness Calls for Proactive Approach,” Police Chief, Vol. $67, \mathrm{n}^{\circ} 12$ (December 2000), pp. 38-44.
} 
Peace Circle in Lamongan to accommodate and empower former terrorist prisoners. ${ }^{30}$ In this foundation, the participation in deradicalizing is not only among the ex-terrorists as an individual, but it facilitates the communication of the ex-terrorist families with society. ${ }^{31}$ Therefore, the collaboration of government with the ex-terrorists to face the issues of terrorism is very crucial.

During some of the collaborative programs conducted by the government and Ali Fauzi, some of the former ex-terrorists attended and shared their experiences with the people, explaining the history of their involvement in terrorist groups and the reasons for their conscious decision to leave terrorist groups. Such programs, conducted by local government to facilitate sharing experiences of ex-terrorists with people, contributed positively to the deradicalization programs. Thus, people can prevent the potential involvement of themselves and their family members with terrorist groups, since they become very well aware of the model and practice of terrorist recruitment and movements.

\section{Conclusion}

The role of the Malang Raya regional government in facing the threat of global terrorism depends on its modalities. The government modalities can be classified in internal and external ones. We can mention as responses originating from within government institutions (internal) the creation of intelligence capabilities and closer collaboration with society, the accurate konowledge of terrorist movements mapping in the area of Malang, and humanist approaches and regular government relations with the pesantren, Islamic groups, and the public. Moreover, the government also adopts proactive responses towards terrorist movements, making efforts to assist the prisoners in prison and collaborating with ex-prisoners as part of deradicalization programs, hiring members who have serious and non bias knowledge of Islam. Meanwhile, one of the external tasks to face the issues of terrorism is the development of excellent relations with pesantren and preaching groups, the support and trust from pesantren and preaching groups, and, as we said, the support from former terrorist inmates.

On the role of the local government we divide the tasks of the government into four: preventive, proactive, curative, and rehabilitative. Preventive roles are related to intelligence activities, mapping of radical groups and holding socialization for the community. In contrast, the proactive role is related to the government's response to the terrorist movements. At the curative level, the government assists terrorist prisoners in prisons. Finally, the rehabilitative role is carried out by cooperating with ex-terrorist inmates as partners in efforts to de-radicalize active defenders of terrorism and safeguarding the public.

\footnotetext{
${ }^{30}$ Gunaratna, Rohan: "Terrorist Rehabilitation and Community Engagement in Southeast Asia," in Schreer, Benjamin and Tan, Andrew T. H. (eds.) (2019): Terrorism and Insurgency in Asia: A Contemporary Examination of Terrorist and Separatist Movements, New York, Routledge, pp. 193-213.

${ }^{31}$ Nurfitri, Leli Eka: "Komunikasi Sosial Keluarga Besar Mantan Teroris Di Desa Tenggulun Kecamatan Solokuro Kabupaten Lamongan”, Thesis, UIN Sunan Ampel Surabaya, (2018), pp.90.
} 


\section{Bibliography}

Anindya, Chaula R.: "Reintegrating Former Terrorist Inmates: Role of Local Government," RSIS Commentaries, 29 November 2018, at https://dr.ntu.edu.sg/bitstream/handle/10220/46754/CO18201.pdf?sequence=1

Balzacq, Thierry. (2011): Understanding Securitisation Theory: How Security Problems Emerge and Dissolve, New York, Routledge.

Bergin, Anthony: “Local Government and Australian Counter-Terrorism Strategy”, Journal of Policing, Intelligence and Counter-Terrorism, Vol.12, n 1 (2017), pp. 74-77.

Buzan, Barry, et al. (1998): Security: A New Framework for Analysis, Colorado, Lynne Rienner Publishers.

Brown, Leslie F: "Twenty-First Century Warfare Will Be Hybrid," Thesis U.S. Army War College, (March 2011), at

http://indianstrategicknowledgeonline.com/web/21\%20cen\%20hybrid.pdf.

Charrett, Catherine: "A Critical Application of Securitization Theory: Overcoming the Normative Dilemma of Writing Security," International Catalan Institute for Peace, Working Paper $n^{0}$ 2009/7 (December 2009), pp. 1-48 at SSRN: https://ssrn.com/abstract=1884149

Comfort, Louise K., and Kapucu Naim: "Inter-Organizational Coordination in Extreme Events: The World Trade Center Attacks, September 11, 2001”, Natural Hazards, Vol.39, n 2 (2006).

Giri, Jay: "Proactive Management of the Future Grid," IEEE Power and Energy Technology Systems Journal, Vol. 2, no 2 (June 2015).

Gunaratna, Rohan: "Terrorist Rehabilitation and Community Engagement in Southeast Asia," in Schreer, Benjamin and Tan, Andrew T. H. (eds.) (2019): Terrorism and Insurgency in Asia: A Contemporary Examination of Terrorist and Separatist Movements, New York: Routledge.

Hopf, Ted: "The Promise of Constructivism in International Relations Theory," International Security, Vol. 23, nº 1 (1998).

Jerard, , at https://www.rsis.edu.sg/wp-content/uploads/2016/01/CO16011.pdf

Limberg, Holger: "Impoliteness and Threat Responses," Journal of Pragmatics Vol. 41, no 7 (2009).

Ministry of Defence Republic of Indonesia (2015): "Buku Putih Pertahanan Indonesia", Ministry of Defence, at https://www.kemhan.go.id/wp-content/uploads/2016/04/BPPI-INDO2015.pdf.

Muradi: "The 88th Densus at the Role and the Problem of Coordination on Counter-Terrorism in Indonesia", J. Pol. \& L. 2 (2009).

Mubah, A.S. (2012): “Teroris versus Globalisasi”, Surabya, PT Revka Petra Media..

Newman, Edward: "Weak States, State Failure, and Terrorism," Terrorism and Political Violence, Vol. 19, no 4 (2007).

Nuraniyah, Navhat: "Returning Indonesian Fighters from Syria and Iraq: Learning from the Past", RSIS Commentaries, 17 February 2015, at https://www.rsis.edu.sg/wpcontent/uploads/2015/02/CO15035.pdf

Nurfitri, Leli Eka: "Komunikasi Sosial Keluarga Besar Mantan Teroris Di Desa Tenggulun Kecamatan Solokuro Kabupaten Lamongan”, Thesis, UIN Sunan Ampel Surabaya, (2018). 
Peou, Sorpong: "Realism and Constructivism in Southeast Asian Security Studies Today: A Review Essay," The Pacific Review, Vol. 15, n 1 (2002).

Ranstorp, M: "Introduction: Mapping Terrorism Research - Challenges and Priorities." In Ranstorp, M. (ed.) (2007): Mapping Terrorism Research: The State of Art, Gaps and Future Direction, New York, Routledge.

Rehm, M. K., and Rehm, W. R: “Terrorism Preparedness Calls for Proactive Approach," Police Chief, Vol. 67, $\mathrm{n}^{\circ} 12$ (December 2000).

Sahrasad, Herdi, and Al Chaidar: "Indonesian Terrorist, ISIS, And Globalization Of Terror: A Perspective," Ahkam: Jurnal Ilmu Syariah, Vol.18, nº 1 (2018).

Sayyidati, Adibah: "Potret Jawa Pos Tentang Islamic State of Iraq and Syria (ISIS) Di Jawa Timur Dalam Perspektif Jurnalisme Perdamaian," Jurnal Pekommas, Vol. 3, nº 1 (April 2018).

Schlesinger, Arthur Jr: "The Humanist Looks at Empirical Social Research," American Sociological Review, Vol. 27, $\mathrm{n}^{\circ} 6$ (December 1962).

Sönmez, S., Apostolopoulos, Y., and P. Tarlow: "Tourism in Crisis: Managing the Effects of Terrorism," Journal of Travel Research, Vol. 38, $\mathrm{n}^{\circ} 1$ (1999).

Tetuko, Bayu and S. Muryantini:"Upaya Pemerintah Indonesia Dalam Menghadapi Penyebaran ISIS,” Jurnal Studi Diplomasi Dan Keamanan, Vol. 8, nº 2 (2016).

Yumitro, Gonda et al., "Terrorism Issues and the Development of Transnational Islamic Movements in The Region of Malang," International Conference on Islam and Muslim Societies (ICONIS) (2018)., at

https://www.academia.edu/37847096/Proceedings_ICONIS_International_Conference_on_Islam_and _Muslim_Societies_-Part_One 